\title{
Assisting Phytoremediation of Heavy Metals Using Chemical Amendments
}

\author{
Md. Mahadi Hasan ${ }^{1}$, Md. Nashir Uddin ${ }^{2}$, Iffat Ara-Sharmeen ${ }^{3}$, Hesham F. Alharby ${ }^{4}$, \\ Yahya Alzahrani ${ }^{4}$, Khalid Rehman Hakeem ${ }^{4}$ (D) and Li Zhang ${ }^{5, *}$ \\ 1 State Key Laboratory of Grassland Agro-Ecosystems, School of Life Sciences, Lanzhou University, \\ Lanzhou 730000, China \\ 2 Department of Biochemistry and Microbiology, School of Health and Life Sciences, North South University, \\ Dhaka 1229, Bangladesh \\ 3 Department of Biochemistry, School of Life Science, Independent University, Dhaka 1229, Bangladesh \\ 4 Department of Biological Sciences, Faculty of Science, King Abdulaziz University, \\ Jeddah 21577, Saudi Arabia \\ 5 Institute of Cell Biology, School of Life Sciences, Lanzhou University, No.222 South TianShui Road, \\ Lanzhou 730000, China \\ * Correspondence: zllily@lzu.edu.cn; Tel.: +86-182-9841-7508
}

Received: 29 July 2019; Accepted: 16 August 2019; Published: 21 August 2019

\begin{abstract}
Phytoremediation is one of the safer, economical, and environment-friendly techniques in which plants are used to recover polluted soils, particularly those containing toxic organic substances and heavy metals. However, it is considered as a slow form of remediation, as plants take time to grow and flourish. Various amendments, including the augmentation of certain chemical substances i.e., ethylenediamine tetraacetic acid (EDTA), ethylene glycol tetra acetic acid (EGTA), and sodium dodecyl sulfate (SDS) have been used to induce and enhance the phytoextraction capacity in plants. Several reports show that chemical amendments can improve the metal accumulation in different plant parts without actually affecting the growth of the plant. This raises a question about the amount and mechanisms of chemical amendments that may be needed for potentially good plant growth and metal phytoremediation. This review provides a detailed discussion on the mechanisms undertaken by three important chemical amendments that are widely used in enhancing phytoremediation (i.e., EDTA, EGTA, and SDS) to support plant growth as well as soil phytoremediation. A core part of this review focuses on the recent advances that have been made using chemical amendments in assisting metal phytoremediation.
\end{abstract}

Keywords: environmental pollution; phytoextraction; cadmium; biostimulation; oxidative damage

\section{Introduction}

Heavy metal pollution is regarded as a serious problem for crop production [1]. In soil ecosystems, the gradual increase in heavy metal levels is a major concern throughout the world [2]. Heavy metal pollution is a vital issue for environmental management due to the rapid increase in anthropogenic activities, including industrialization, transportation, and urbanization. Several sources of heavy metals include medical waste, the combustion of coal, petrol, mining, fertilizers, smelting, and pesticides, which are adding heavy metals to the environment [3,4]. Among these heavy metals, cadmium $(\mathrm{Cd})$, lead $(\mathrm{Pb})$, aluminum $(\mathrm{Al})$, zinc $(\mathrm{Zn})$, manganese $(\mathrm{Mn})$, chromium $(\mathrm{Cr})$, and copper $(\mathrm{Cu})$ are considered as common toxic heavy metals [1].

Toxic heavy metals considered as phytotoxic agents to plants that affect the plant morphological and physiological processes such as lower growth rate, stomatal movement and nutrient imbalance, 
and photosynthetic processes result in the oxidative damage [5]. Due to increased contamination of soil by toxic metal components, it is important to use necessary techniques for cleaning up heavy metals from contaminated soil, which requires an effective and reasonable solution. Some modern techniques that have been used for the remediation of heavy metals are based on the biological, chemical, and physical approaches [6]. Phytoremediation is one of the biological approaches used for the remediation of soils. Phytoremediation is preferable due to its safety and lower cost as compared to physical and chemical remediation [6]. The technologies of metal phytoremediation include phytoextraction, phytostabilization, and phytovolatilization [7]. Among these, phytoextraction is one of the promising techniques being used for reclaiming the metal polluted soils [1].

However, the heavy metal extraction by plants is usually limited by the availability of heavy metals in soils. The application of chemical enhanced technology is one of the prevalent approaches, which helps the uptake of heavy metals and their translocation in the aboveground parts of plants $[4,8]$.

Several chemical amendments have been used for the enhancement of phytoextraction processes. In recent years, chemical amendments including ethylenediamine tetraacetic acid (EDTA), ethylene glycol tetraacetic acid (EGTA), and sodium dodecyl sulfate (SDS) are widely used for soil remediation applications, which can bring potential metal leaching risk. EDTA is considered as having the most potential and most studied chemical amendment, and is used to increase the phytoextraction of metals from contaminated soils [9].

Therefore, it is important to increase phytoremediation efficiency through the phytoextraction processes of heavy metals. The phytoremediation of heavy metals in plants may be enhanced through an emerging chemical amendments technology. Our present review attempts to describe the potential benefits of chemical amendments in phytoremediation research.

\section{Source of Heavy Metal Pollution, Ecotoxicity, and Approaches for Remediation}

In general, heavy metals originate from anthropogenic and natural sources. Different sources of heavy metals were identified such as (a) industrial sources, (b) domestic effluent, (c) agricultural sources, and (d) natural sources such as the atmosphere (Figure 1). It has been reported that most of the areas in the world such as China, Japan, and Indonesia have been contaminated by $\mathrm{Cd}, \mathrm{Cu}$, and $\mathrm{Zn}$ due to mining and agricultural operations [6].

In terrestrial ecosystems, the heavy metal contaminations are increasing due to anthropogenic activities, which are known to be liable for ecotoxicity. The largest availability of heavy metals toxicity occurs in soil and aquatic ecosystems, whereas the smaller portion of metals available in the atmosphere form of vapors or particulate. In soil, the major heavy metal ranges vary from 0.01 to $0.7 \mathrm{ppm} d \mathrm{w}$ of $\mathrm{Cd}, 2$ to $200 \mathrm{ppm} \mathrm{dw}$ of $\mathrm{Pb}, 10$ to $300 \mathrm{ppm} d w$ of $\mathrm{Zn}, 5$ to $3000 \mathrm{ppm} \mathrm{dw}$ of $\mathrm{Cr}$, and 7000 to 55,000 ppm $\mathrm{d} w$ of Fe etc. [10]. Heavy metal pollution in soils is becoming increasingly common in the agricultural sector, and affects food safety and crop growth. The metal toxicity in plants is not the same; it varies with plant species, metal concentration, soil $\mathrm{pH}$, soil composition, specific metal and chemical form, etc. According to Misra and Mani [11], the range of vital heavy metal in plants is 0.1 to $2.4 \mu \mathrm{g}^{-1} \mathrm{dw}$ for $\mathrm{Cd}, 1$ to $13 \mu \mathrm{g}^{-1} \mathrm{dw}$ for $\mathrm{Pb}, 0.02$ to $7 \mu \mathrm{g}^{-1} \mathrm{dw}$ for As, 8 to $100 \mu \mathrm{g}^{-1} \mathrm{dw}$ for $\mathrm{Zn}, 0.2$ to $1 \mu \mathrm{g}^{-1} \mathrm{dw}$ for $\mathrm{Cr}$, $140 \mu \mathrm{g}^{-1} \mathrm{dw}$ for Fe, etc.

Toxic heavy metal is hazardous to the environment. Therefore, heavy metal remediation in the soil is very important [12]. Over the past few decades, various techniques were employed for the remediation of toxic heavy metals. The preferred strategies were selected for the remediation of heavy metal from the environment based on their technical complexity and cost [13]. The techniques include physical, chemical, and biological methods [14]. 


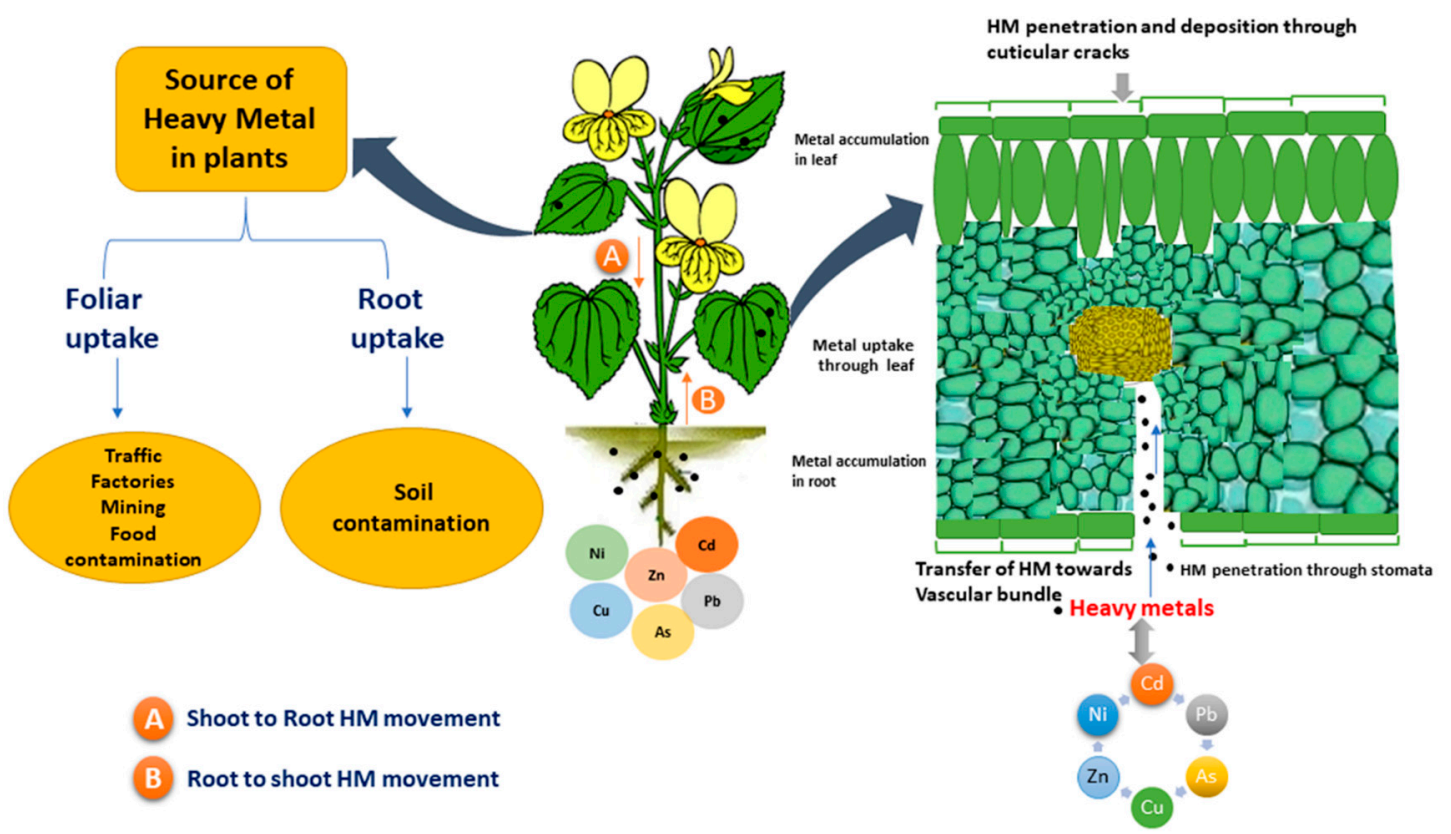

Figure 1. Sources of heavy metals, and foliar, root uptake of heavy metals in plants.

Traditionally, the contaminated soils are cleaned up by excavation or removing the soils from the land sites. The toxic metals problems in the soil may also arise due to the transportation of contaminants that are closely adjacent to the soils [15]. Soil washing is another strategy to eliminate soil metal contaminants, but it has been reported that this is unsuitable for plant growth and development due to the hindrance of biological and chemical activities [16]. Chemical methods are not preferable due to alterations in the soil texture and structure, expense, and the generation of high quantities of sludge $[16,17]$.

\subsection{Physiochemical Techniques}

The physiochemical technique includes excavation, leaching, landfill, and thermal treatment (bioreactor) approaches. Nevertheless, these processes are fast but costly, and have detrimental effects on the soil properties $[13,18]$. These techniques are not completely suitable for heavy metal remediation, and only change the form of the problem without remediating the pollutants thoroughly [19].

\subsection{Biological Approaches}

Heavy metals are removed from the environment through natural remediation coordinated by microorganisms and plants [14]. Biological remediation is a preferable method as it is natural, cost-effective, environmentally friendly, and has wider public support [20]. There are several approaches, such as bioaugmentation, biostimulation, bioleaching, composting, bioreactors, bioremediation, and phytoremediation [21]. Biological approaches are considered superior to physiological approaches, because these processes use solar energy and ensure that the soil properties are conserved [20]. Bioremediation is a technique by which heavy metals are removed from the environment $[19,22]$. Bacterial strains such as P. aeruginosa and Bacillus spp. can remediate metals such as zinc and copper in this context [23]. Bioremediation can be done using biostimulation, biofilters, treated and pumped methods, bioventing, bioreactors, composting, land forming, bioaugmentation, and intrinsic bioremediation [24]. The efficiency of phytoremediation can be increased if microbes are used [25].

\subsubsection{Phytoremediation of Heavy Metals}

Phytoremediation is a part of the emerging green technology being used for the uptake of various heavy metals in different amounts from the soil and storage of them in parts of the plant that can be 
harvested [26]. With changes in soil properties, plants can tolerate pollutants [27]. Soils containing heavy metals can be easily treated through phytoremediation, and the biomass that is formed during the process can be further applied in biodiesel production. Thus, bioenergy crops such as Brassica species, which are known to accumulate toxic metals, are increasingly suitable for this purpose. Some plants can accumulate pollutants in tissues [28]. The Jerusalem artichoke (Helianthus tuberosus L.) is known to be an energy crop that is used for the phytoremediation of soils contaminated by heavy metals. It is more suitable for the phytoextraction of heavy metals among the energy crops. The highest heavy metal uptake was observed at a dose of $60 \mathrm{Mg} \mathrm{DMha}^{-1}$ in the Jerusalem artichoke [29].

Hyperaccumulating plants are fit to grow on soils contaminated with heavy metals and can be used to remove pollutants [19]. Plants that contain greater than $10,000 \mathrm{mg} / \mathrm{kg}$ dry weight of $\mathrm{Zn}$ or Mn or more than $1000 \mathrm{mg} / \mathrm{kg}$ dry weight of $\mathrm{Ni}, \mathrm{Cu}$, or $\mathrm{Pb}$ or greater than $100 \mathrm{mg} / \mathrm{kg}$ dry weight of $\mathrm{Cd}$ in contaminated areas are considered as hyperaccumulating plants. There are several families of plants that are known to hyperaccumulate toxic heavy metals. Some such important plant families are Lamiaceae, Fabaceae, Scrophulariaceae, Asteraceae, Euphorbiaceae, and Brassicaceae, which are usually used in the phytoremediation processes. Other than that, there have been reports of heavy metal hyperaccumulation in about 500 plant species [30]. Plants with greater hyperaccumulating abilities include Alyssum bertolonii, Thlaspi caerulescens, Calendula officinalis, and Tagetes erecta [31]. Higher concentrations of $\mathrm{Ni}, \mathrm{Zn}$, and $\mathrm{Cd}$ are best gathered by Thlaspi caerulescens [32]. This plant can accumulate $500-52,000 \mathrm{mg} \mathrm{kg}^{-1}$ of $\mathrm{Zn}$ and $0.3-1020 \mathrm{mg} \mathrm{kg}^{-1}$ of $\mathrm{Cd}$. Trees are more suitable for phytoremediation because of their greater root systems and biomass [19], although trees take more time in accumulating metals, even in low quantities. This issue could be solved by using fast-growing plants instead of trees [33]. For an example, the Poplus alba is a deciduous tree, which can accumulate zinc (Zn) in different plant parts such as leaves, stems, and roots. An increasing trend of $\mathrm{Zn}$ accumulation was observed in the leaves of Poplus alba with the application of SDS [34]. Phytoremediation depends on the ability of the plants to gather increased levels of toxic metals within their tissues [35]. Some plants contain enzymes that can break down a number of organic compounds. However, pollutants that are inorganic cannot be degraded with these enzymes. Thus, there is a need to ensure that inorganic pollutants be less available in soils or extracted and accumulated in different parts of the plants and also reduce volatile versions of inorganic pollutants [36]. Energy recovery strategies can be used to produce bioenergy from plant biomass, such as to form biodiesel. Fuel gas, char, and bio-oil can be produced via pyrolysis, during which the biomass undergoes thermal degradation without oxygen [37]. Soils greatly polluted with toxic heavy metals can be remediated easily by growing plants that are tolerant to more than one heavy metal, can produce a good amount of harvestable biomass with enhanced growth rates, and are highly competitive [30].

\subsubsection{Problems with Heavy Metals of Remediation with Phytoremediation}

Phytoremediation performance could be affected by several processes such as the rate of contaminant uptake by plant roots, the availability of toxic metal ions in the soil, and the root-to-shoot movement of the metal ions [38]. Plants store the heavy metals in the different parts of the plant such as in the leaf, stem, and root [26]. Although phytoremediation is considered as a green technology, it has some problems or limitations in the case of remediation of soils. According to Koptsik [39], there are some problems or limitations of phytoremediation as follows:

- It depends on the local climate, weather, and seasonal conditions.

- It requires more time to remediate pollutants from the soil.

- It is suitable only for low-polluted territories.

- It depends on the depth of the root system and solubility of the pollutants.

- Pollutants may enter the trophic chains and adjacent media. 


\section{Assistance of Chemical Amendments to Increase the Efficiency of Phytoremediation}

High heavy metal concentrations in plant tissues and biomass are considered as a key factor for the successful phytoremediation of heavy metal polluted soils [40]. The natural levels of heavy metals are relatively high in the Earth's crust, and most of these are phytoavailable and low soluble [41]. Chemical amendments have a key role to compensate for relatively low heavy metal availability in soil, and it helps the plants uptake and translocate metals toward the shoot [42]. Different kinds of chemical amendments or chelating agents have been used and tested to increase the bioavailability of metals in plants and facilitate the transport of metals between the roots and shoots. The most important of the three chemical amendments are EDTA, EGTA, and SDS, which have been widely used in recent years (Figure 2).
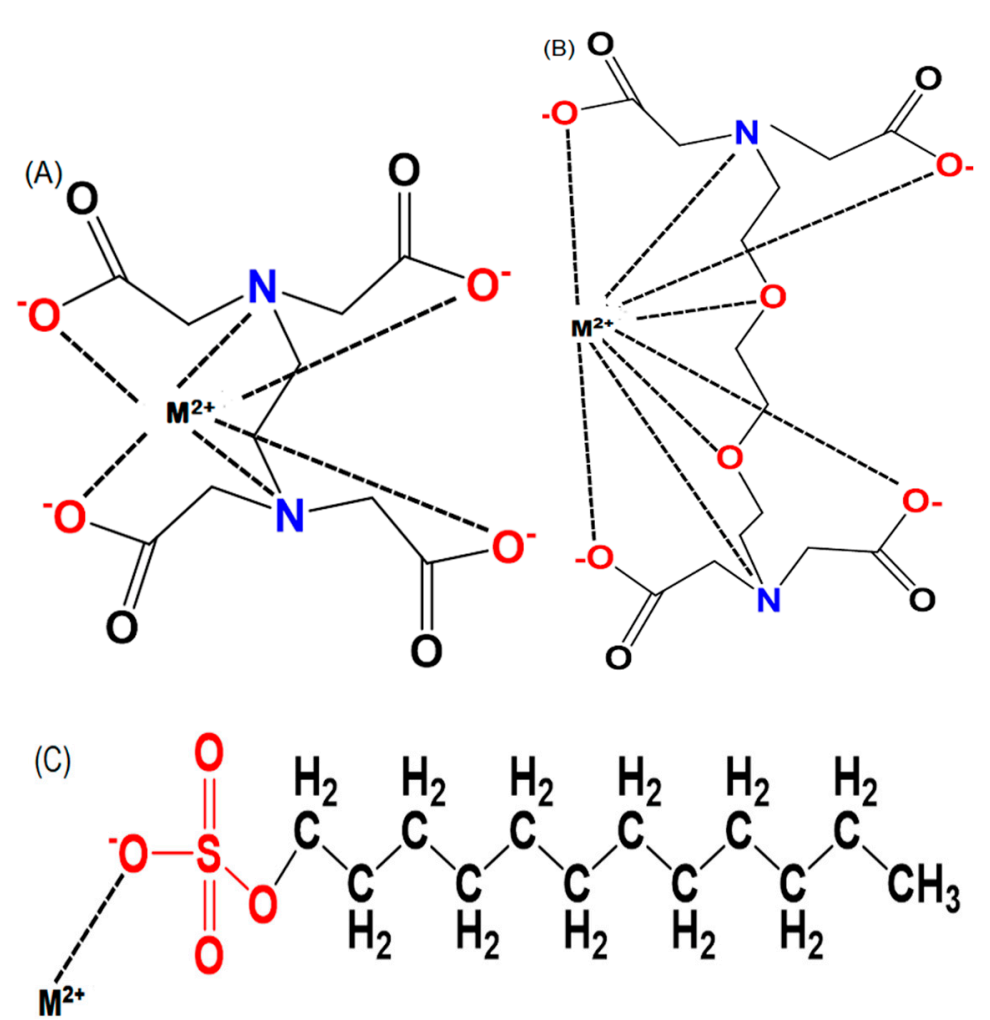

Figure 2. Chemical structure of (A) ethylene diamine tetraacetic acid (EDTA), (B) ethylene glycol tetraacetic acid (EGTA), (C) sodium dodecyl sulfate (SDS), and binding with metals, $\mathrm{M}^{2+}\left(\mathrm{Cd}^{2+}, \mathrm{Pb}^{2+}\right.$ etc.).

\subsection{Assisting of Phytoremediation by EDTA}

Ethylenediamine tetraacetic acid, also known as EDTA, is used frequently in the agricultural sector due to its ability to mobilize heavy metals. EDTA enhances metal uptake through the roots and also supports metal xylem loading (Figure 3).

This has also been reported in previous studies [44]. The increased uptake occurs due to the production of soluble metal-EDTA complexes [45]. Most plants are able to take up metal-EDTA complexes [46], especially hyperaccumulator species [47]. The effect of EDTA depends on the plant species, heavy metal, and type of soil, ranging from 0 to 200-fold higher accumulations [42]. Cu, Zn, $\mathrm{Pb}, \mathrm{Ni}$, and $\mathrm{Cd}$ uptake was enhanced by EDTA in Zea mays and Lolium perenne [48]. Lead accumulation increased fourfold in the Sedum alfredii roots [49] and twofold in Vicia faba seedlings in a 24-h experiment [50]. 

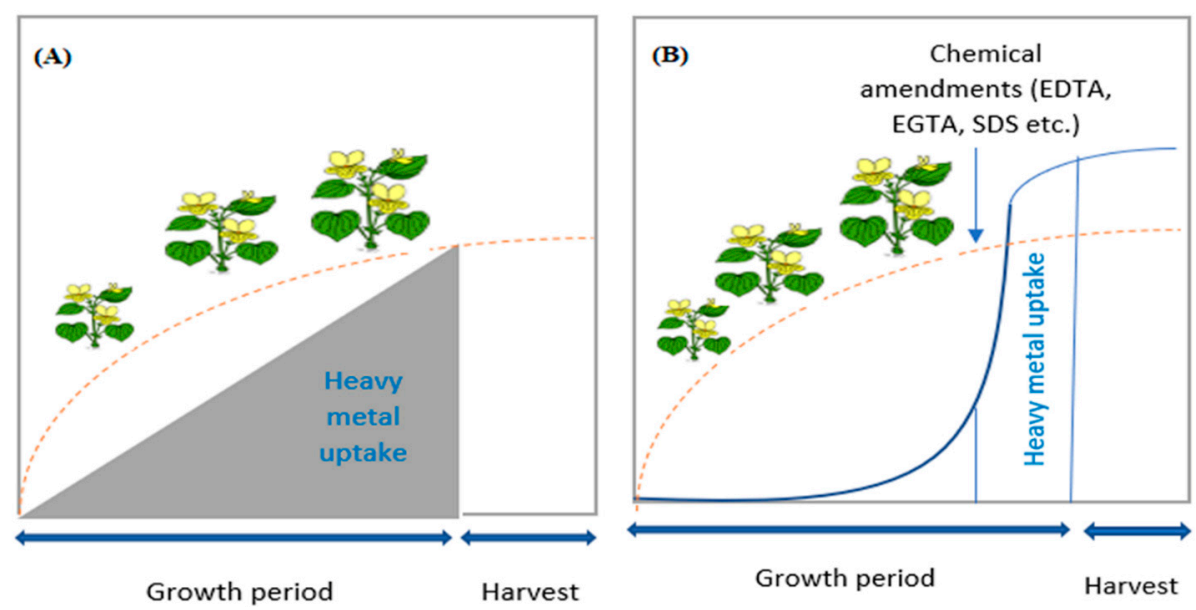

Figure 3. Chemical amendments assisting the heavy metal uptake in the plants, adapted from Souza et al. [43]. Figure (A) depicts that a hyperaccumulator plant accumulates the heavy metal gradually and constantly during the entire life cycle of the plant, whereas Figure (B) shows that the heavy metal behavior of a non-hyperaccumulator plant is relatively slow, but the metal uptake increases quickly after the application of chemical amendments along with metals.

The metal uptake rate or concentration in plants depends on the chemical amendments dose during the application of chemical amendments. The uptake of toxic metals rate may reach a maximum in plants at a certain amendments dose level. Before treatment, the lead $(\mathrm{Pb})$ concentration was $0.025 \mathrm{mg} / \mathrm{g}$ in Typha sp. The concentration was increased to $0.846 \mathrm{mg} / \mathrm{g}$, while $1 \mathrm{~mL}$ of EDTA was added along with $1 \mathrm{ppm}$ of lead. Similarly, the copper $(\mathrm{Cu})$ was increased $0.030 \mathrm{mg} / \mathrm{g}$ to $0.522 \mathrm{mg} / \mathrm{g}$, when $1 \mathrm{~mL}$ of EDTA was added in combination with $1 \mathrm{ppm}$ of $\mathrm{Cu}$. Cd concentration was increased by $51.98 \%$ in the shoot during the application of EDTA with Cd [45].

In another study, EDTA caused a 15-fold increased uptake of lead in the roots of Vetiveria zizanioides. The concentrations of EDTA solution $\left(0-10 \mathrm{mmol} \cdot \mathrm{kg}^{-1}\right.$ soil) were added under the exposure of $1000 \mathrm{mg} \cdot \mathrm{kg}^{-1}$ of $\mathrm{Pb}$ in the form of $\mathrm{Pb}\left(\mathrm{NO}_{3}\right)_{2}$ for 14 days. They concluded that $10 \mathrm{mmol} \cdot \mathrm{kg}^{-1}$ of EDTA treatment was best regarding the lead $(\mathrm{Pb})$ uptake in Vetiveria zizanioides [51]. The maximum $\mathrm{Pb}$ concentrations in the shoot were found in Canavalia ensiformis L. when $0.5 \mathrm{~g} \cdot \mathrm{kg}^{-1}$ of EDTA was used for 40 days with the application of $1800 \mathrm{mg} \cdot \mathrm{kg}^{-1}$ of $\mathrm{Pb}$ as $\mathrm{Pb}\left(\mathrm{NO}_{3}\right)_{2}$ [52]. A study showed a higher uptake of lead, but no other heavy metals from contaminated soils [53]. Under the exposure of $\mathrm{Cd}$ as $\mathrm{CdCl}_{2}\left(50 \mathrm{mg} \cdot \mathrm{kg}^{-1}\right)$, the shoot concentrations of $\mathrm{Cd}$ significantly increased at a rate of $0.5 \mathrm{~g} \cdot \mathrm{kg}^{-1} \mathrm{EDTA}$ in Helianthus annuus [54] (Table 1).

Phytoextraction using EDTA can be made more efficient with the proper mix of organic chelators, metals, and appropriate plant species [70].

The mechanism of EDTA increasing metal uptake is not fully understood yet. There are various steps involved in the entrance of metals from the soil to the roots, which determines the rate of uptake and also the capability of a plant to take in heavy metals. The uptake of metals into the roots involves: (i) the movement of soluble metals to plant roots through mass flow or diffusion [71], (ii) adsorption on roots, and (iii) attachment to functional groups within the rhizoderm cell surface [72]. The adsorption of metals into the plant root surface has been observed in various studies [73]. The metal-EDTA complexes form affects almost all of the steps previously mentioned of metals uptaking through plant roots. Initially, EDTA allows the diffusion of metals through the roots by (i) increasing their concentration in soil by desorbing metals and (ii) lowering the apparent diffusion coefficient of metals in metal-EDTA complex forms [71]. Since metal-EDTA complexes carry a neutral charge, they are not attached or blocked by polysaccharides or carboxyl groups in the rhizoderm cell surface. In this way, EDTA allows the movement of metals directly into the roots. However, there have been various hypotheses about whether metal-EDTA complexes dissociate just before entering the plant roots or 
enter as they are [74]. In some studies, it was shown that EDTA form complexes in solution, then enter plants [61]. A study involving 14C-labeling showed that indeed, the full metal-EDTA complex is absorbed, with particular selectivity toward lower charged complexes in Swiss chard. Sarret et al. [75] mentioned that these metal-EDTA complexes are nontoxic and break down after entering the roots, forming free heavy metal ions that could induce phytotoxicity. Inductively coupled plasma mass spectrometry (ICP-MS) analysis of xylem sap showed the presence of metal-EDTA complexes and the absence of EDTA individually in Hordeum vulgare grown in contaminated soil amended with EDTA. Schaider et al. [76] showed the presence of complexes in xylem sap such as Cd-EDTA, Pb-EDTA, and Fe-EDTA.

Table 1. Effects of heavy metals on the plants with different growing conditions along with chemical amendments.

\begin{tabular}{|c|c|c|c|c|}
\hline & Heavy & Growing & Chemical & References \\
\hline Scientific Name & Metals & Conditions & Amendments & \\
\hline $\begin{array}{l}\text { Calendula } \\
\text { officinalis }\end{array}$ & $\mathrm{Cd}$ & Pot & $\begin{array}{c}\text { EDTA, EGTA, } \\
\text { SDS }\end{array}$ & [55] \\
\hline Tagetes erecta & $\mathrm{Pb}$ & Pot & EDTA & [56] \\
\hline $\begin{array}{l}\text { Impatiens } \\
\text { walleriana }\end{array}$ & $\mathrm{Cd}$ & Pot & EDTA & [57] \\
\hline Medicago sativa & $\mathrm{Cr}$ & Pot & EDTA & [58] \\
\hline Tribulus terrestris & $\mathrm{Cd}, \mathrm{Pb}$ & Pot & EDTA & [59] \\
\hline Helianthus annuus & $\mathrm{Cd}, \mathrm{Ni}$ & Pot & EDTA & [54] \\
\hline Dianthus chinensis & $\mathrm{Cd}, \mathrm{Zn}, \mathrm{Pb}$ & Pot & EDTA & [60] \\
\hline Vetiver zizanioides & $\mathrm{Cd}, \mathrm{Zn}, \mathrm{Pb}$ & Pot & EDTA & [60] \\
\hline Canavalia ensiformis L. & $\mathrm{Pb}$ & Pot & EDTA & [52] \\
\hline Brassica carinata & $\mathrm{Cd}, \mathrm{Cr}, \mathrm{Pb}$ & Pot & EDTA & [44] \\
\hline Brassica juncea & $\mathrm{Cd}, \mathrm{Cr}, \mathrm{Pb}$ & Pot & EDTA & [44] \\
\hline Brassica juncea & $\mathrm{Pb}$ & Pot & EDTA & [61] \\
\hline Phaseolus vulgaris L. & $\mathrm{Pb}, \mathrm{Zn}, \mathrm{Cu}$ & Pot & EDTA & [62] \\
\hline $\begin{array}{l}\text { Zea mays L. cv. } \\
\text { Nongda } 108\end{array}$ & $\mathrm{~Pb}, \mathrm{Zn}, \mathrm{Cu}$ & Pot & EDTA & [62] \\
\hline $\begin{array}{c}\text { Brassica juncea } \mathrm{L} . \\
\text { Czern. }\end{array}$ & $\mathrm{Pb}, \mathrm{Zn}$ & Pot & EDTA & [63] \\
\hline Triticum aestivum & $\mathrm{Pb}, \mathrm{Zn}$ & Pot & EDTA & [63] \\
\hline Mirabilis jalapa $\mathrm{L}$. & $\mathrm{Cd}$ & Pot & EDTA, EGTA & [64] \\
\hline Althaea rosea & $\mathrm{Cd}$ & Pot & EDTA, EGTA, SDS & [65] \\
\hline Mirabilis jalapa & $\mathrm{Cd}$ & Pot & EDTA, EGTA & [64] \\
\hline Cicer arietinum & $\mathrm{Cd}$ & Pot & EGTA & [66] \\
\hline Sesbania exaltata & $\mathrm{Pb}$ & Pot & EDTA, EGTA & [67] \\
\hline Calendula officinalis & $\mathrm{Cd}$ & Pot & EGTA, SDS & [68] \\
\hline Althaea rosea & $\mathrm{Cd}$ & Pot & EGTA, SDS & [68] \\
\hline Halimione portulacoides & $\mathrm{Cu}$ & Field & SDS & [69] \\
\hline Populus alba & $\mathrm{Zn}$ & Pot & SDS & [34] \\
\hline
\end{tabular}

\subsection{Assisting of Phytoremediation by EGTA}

EGTA, or ethylene glycol tetraacetic acid, is a widely used chelating agent. Similar to EDTA, the four carboxyl groups dissociate and produce four protons (Figure 2). The two $\mathrm{N}$ atoms of the two amino groups have unshared pairs of electrons each. EGTA has been shown to have more affinity for Ca ions, but less affinity toward Mg ions. Such synthetic chelators have been successfully used for phytoextraction [77]. The factor to consider for using EGTA is that it increases the uptake of heavy metals by plants more efficiently. Sakouhi et al. [66] reported that applying EGTA increased Pb accumulation by more than $80 \%$ in parts of Cicer arietinum plants above ground. After the application of $1 \mathrm{mmol} \mathrm{kg}{ }^{-1}$ of EGTA in A. rosea, the maximum total Cd content was observed, which was increased by $72 \%$ [68]. In Mirabilis Jalapa, Cd concentration was increased by $43.27 \%$ in the shoot under EGTA 
treatment along with $\mathrm{Cd}\left(25 \mathrm{mg} \cdot \mathrm{kg}^{-1}\right)$ [64]. The $\mathrm{Cd}$ concentration was at a maximum in the shoots when $1.0 \mathrm{mmol} \cdot \mathrm{kg}^{-1}$ was used. In Calendula officinalis, $30-100 \mathrm{mg} \cdot \mathrm{kg}^{-1}$ of $\mathrm{Cd}$ as $\mathrm{CdCl}_{2}$ was added to the soil, and it was observed that the total Cd increases up to $217 \%$ with the application of EGTA alone. They concluded that the use of $1.0 \mathrm{mmol} \mathrm{kg}^{-1}$ EGTA showed the greatest effect among the treatments [55] (Table 1).

\subsection{Assisting of Phytoremediation by SDS}

SDS is a surfactant that is most commonly used in detergents, but it can also be used for heavy metal and organic contaminant remediation from soil [34]. SDS can ameliorate solubilities of various hydrocarbons and heavy metals such as zinc, cadmium, lead, and copper, making their removal easier, both in phytoremediation trails involving herbaceous species [78] and soil flushing [79]. Surfactants contain a hydrophobic portion that has less affinity for aqueous solutions, and the hydrophilic polar portion, which has a higher affinity for aqueous solutions. Thus, surfactants are amphiphilic. Anionic surfactants such as SDS are amphipathic, as they can interact with both non-polar and polar macromolecules, causing membrane damage and even oxidative stress [80]. However, the direct involvement of SDS in plant remediation trials has not yet been widely investigated, because some strains of Pseudomonas can degrade SDS by using it as a carbon source $[81,82]$ and photoelectrochemical reactions [83]. It has been observed that SDS can increase the dry biomass of plants such as Althaea rosea, and also promote $\mathrm{Cd}$ accumulation in roots and shoots [65]. Calendula and Althaea rosea provide some evidence that $\mathrm{Zn}$ accumulation changes with the presence of SDS [34]. When $1 \mathrm{mM}$ of $\mathrm{Zn}$ was added in combination with $0.5 \mathrm{mM}$ of SDS, the $\mathrm{Zn}$ translocation was increased toward basal leaves in Poplus alba [34]. The maximum Cd concentration was observed in the shoots and roots in Althaea rosea, when $1.0 \mathrm{mmol} \mathrm{kg}{ }^{-1}$ was added among the single SDS treatments $\left(0.5 \mathrm{mmol} \cdot \mathrm{kg}^{-1}\right.$ to $\left.2 \mathrm{mmol} \cdot \mathrm{kg}^{-1}\right)$ [68]. In Calendula officinalis, when the applied soil Cd contamination was $30 \mathrm{mgkg}^{-1}$, the Cd concentrations in the shoot increased significantly under $0.5-2.0 \mathrm{mmolkg}^{-1} \mathrm{SDS}$ treatments. For the higher concentration of $100 \mathrm{mg} \cdot \mathrm{kg}^{-1} \mathrm{Cd}$ as $\mathrm{CdCl}_{2}$, the application of SDS $\left(0.5-2.0 \mathrm{mmol} \cdot \mathrm{kg}^{-1}\right)$ was observed to increase the $\mathrm{Cd}$ concentrations in the shoot. They concluded that the maximal shoot $\mathrm{Cd}$ concentrations were observed when $2.0 \mathrm{mmol} \cdot \mathrm{kg}^{-1}$ SDS were used [55] (Table 1).

\section{Challenges with Chemical Amendments}

Chemical amendments are useful in phytoremediation methods used to phytoextract heavy metals from contaminated soil; however, adding EDTA, EGTA, and SDS also have a few limitations [84], such as toxic effects toward soil microbes [85], soil enzyme activities, and on cultivated plant species [86]. Due to metal mobilization during extended periods, the chemical-assisted phytoextraction increases the risk of adverse environmental effects. Chemical amendments can disrupt chemical properties and the physical structures of soil by dissolving minerals.

EDTA and its metal complexes are not just highly toxic, but also non-biodegradable and could persist for many weeks [87]. EDTA is an exogenous substance that has adverse environmental effects on soils. EDTA is said to persist within the soil for six months or more [86]. EDTA-facilitated metal movement through soil could occur post-growing season. A monitoring study conducted by [88] mentioned a similar movement of metals such as $\mathrm{Zn}, \mathrm{Cu}, \mathrm{Pb}$, and $\mathrm{Cd}$ using EDTA post-treatment while observing the behavior of heavy metals. Grcman et al. [89] observed that EDTA could leave phytotoxic effects on plants such as red clover. Luo et al. [90] reported similar phytotoxic effects by EDTA even after six months since addition to the soil.

A recent study by Krujatz [91] found that EDTA reduced the toxicity of $\mathrm{Ni}^{2+}$ and $\mathrm{Cd}^{2+}$ within the stoichiometric ratio, but still inhibited the growth of Pseudomonas brassicacearum above the ratio. EDTA also has potentially toxic effects on fungi and bacteria living in soil [88] and plants [84]. Ruley et al. [92] observed lower photosynthetic activity in seedlings of Sesbania drummondii that were exposed to EDTA solutions. The toxicity of metals induced by EDTA is due to increased metal uptake [93]. Other phytotoxic effects caused by EDTA may occur due to enhanced metal uptake 
by plants [94]. Other authors reported results of lower plant biomass when EDTA is present [95]. The toxicity symptom seen in Brassica juncea and Lolium perenne showed a significant decrease in their biomass [87]. In Typha angustifolia, there was a significant decrease in biomass and plant height, resulting in stunted growth [96].

Metal leaching enhanced by chemical amendments depends on various factors, such as:

- $\quad$ Plant-related: root type, species, type and amount of root exudates, age [52,97];

- Soil related: soil texture, $\mathrm{pH}$, organic contents, competing ions, carbonates, biological and microbial conditions, soil water holding capacity, cation exchange capacity (CEC), soil redox potential, soil-buffering capacity [98];

- Metal related: concentration and type of metal, EDTA, EGTA, and SDS-binding capacity to a specific metal, whether single or more than one metal contamination $[61,99]$.

\section{Conclusions and Future Direction}

Heavy metals can cause serious environmental pollution, as they can accumulate in soils and persist for a long time, and even possibly enter the food chain. The chemical amendment-induced remediation of heavy metals by plant species is an effective technique, because it has high binding capacities toward the majority of the heavy metals. Among the three chemical amendments, EDTA is known to be the most efficient organic ligand that can increase metal uptake, solubilization, and translocation, as it can form highly stable and soluble metal-EDTA complexes. Most probably, iron (Fe) is the best metal to bind with EDTA due to its high affinity to ferric ions. Metal phytoremediation enhanced by EDTA, EGTA, and SDS can be affected depending on various biogeochemical processes found in plants, metal, and the soil. Chemical amendment capacity is an important aspect, in order to reduce the time and cost needed for heavy metal contaminated soil. This can be done by increasing the heavy metal bioaccumulation index in plants.

Author Contributions: M.M.H. wrote the initial draft of the manuscript, M.N.U. modified and edited the figure and table, I.A.-S., H.F.A., K.R.H. and Y.A. were involved in the compilation of the final draft, and L.Z. revised the final manuscript.

Funding: This research did not receive any external funding.

Acknowledgments: The authors are thankful to the School of Life Sciences, Lanzhou University, China, for the financial support in the form of a postdoctorate fellowship to M.M.H. We thank Mirza Hasanuzzaman, Department of Agronomy, Sher-e-Bangla Agricultural University, and Katherine Li, Director of the office of external affairs, North South University for the critical reading and formatting of the final manuscript.

Conflicts of Interest: The authors declare no conflict of interest.

\section{References}

1. Bhat, J.A.; Shivaraj, S.M.; Singh, P.; Navadagi, D.B.; Tripathi, D.K.; Dash, P.K.; Solanke, A.U.; Sonah, H.; Deshmukh, R. Role of Silicon in Mitigation of Heavy Metal Stresses in Crop Plants. Plants 2019, 8, 71. [CrossRef]

2. Fuentes, A.; Almonacid, L.; Ocampo, J.A.; Arriagada, C. Synergistic interactions between a saprophytic fungal consortium and Rhizophagus irregularis alleviate oxidative stress in plants grown in heavy metal contaminated soil. Plant Soil 2016, 407, 355-366. [CrossRef]

3. Li, Y.; Luo, J.; Yu, J.; Xia, L.; Zhou, C.; Cai, L.; Ma, X. Improvement of the phytoremediation efficiency of Neyraudia reynaudiana for lead-zinc mine-contaminated soil under the interactive effect of earthworms and EDTA. Sci. Rep. 2018, 8, 6417. [CrossRef] [PubMed]

4. Jiang, M.; Liu, S.; Li, Y.; Li, X.; Luo, Z.; Song, H.; Chen, Q. EDTA-facilitated toxic tolerance, absorption and translocation and phytoremediation of lead by dwarf bamboos. Ecotoxicol. Environ. Saf. 2019, 170, 502-512. [CrossRef] [PubMed]

5. Nakbanpote, W.; Meesungnoen, O.; Prasad, M.N.V. Potential of Ornamental Plants for Phytoremediation of Heavy Metals and Income Generation. In Bioremediation and Bioeconomy; Elsevier: Amsterdam, The Netherlands, 2016; pp. 179-217. 
6. Ashraf, M.A.; Hussain, I.; Rasheed, R.; Iqbal, M.; Riaz, M.; Arif, M.S. Advances in microbe-assisted reclamation of heavy metal contaminated soils over the last decade: A review. J. Environ. Manag. 2017, 198, 132-143. [CrossRef]

7. Ernst, W.H.O. Phytoextraction of mine wastes-Options and impossibilities. Chem. Erde-Geochem. 2005, 65, 29-42. [CrossRef]

8. Yan, D.Y.S.; Lo, I.M.C. Phyrophosphate coupling with chelant-enhanced soil flushing of field contaminated soils for heavy metal extraction. J. Hazard. Mater. 2012, 199, 51-57. [CrossRef] [PubMed]

9. Chen, Y.; Li, X.D.; Shen, Z.G. Leaching and uptake of heavy metals by ten different species of plants during an EDTA-assisted phytoextraction process. Chemosphere 2004, 57, 187-196. [CrossRef] [PubMed]

10. Nagajyoti, P.C.; Lee, K.D.; Sreekanth, T.V.M. Heavy metals, occurrence and toxicity for plants: A review. Environ. Chem. Lett. 2010, 8, 199-216. [CrossRef]

11. Misra, S.G.; Mani, D. Soil Pollution; Ashish Publishing House: Punjabi Bagh, India, 1991.

12. Taj, Z.Z.; Rajkumar, M. Perspectives of plant growth-promoting actinomycetes in heavy metal phytoremediation. In Plant Growth Promoting Actinobacteria; Springer: Singapore, 2016; pp. 213-231.

13. Mahar, A.; Wang, P.; Ali, A.; Awasthi, M.K.; Lahori, A.H.; Wang, Q.; Li, R.; Zhang, Z. Challenges and opportunities in the phytoremediation of heavy metals contaminated soils: A review. Ecotoxicol. Environ. Saf. 2016, 126, 111-121. [CrossRef]

14. Alamgir, M. The effect of soil properties to the extent of soil contamination with metals. In Environmental Remediation Technologies for Metal-Contaminated Soils; Springer: Cham, Switzerland, 2016; pp. 1-19.

15. Thakur, S.; Singh, L.; Wahid, Z.A.; Siddiqui, M.F.; Atnaw, S.M.; Din, M.F.M. Plant-driven removal of heavy metals from soil: Uptake, translocation, tolerance mechanism, challenges, and future perspectives. Environ. Monit. Assess. 2016, 188, 206. [CrossRef] [PubMed]

16. Tangahu, B.V.; Sheikh, A.S.R.; Basri, H.; Idris, M.; Anuar, N.; Mukhlisin, M. A review on heavy metals (As, Pb, and $\mathrm{Hg}$ ) uptake by plants through phytoremediation. Int. J. Chem. Eng. 2011. [CrossRef]

17. Zubair, M.; Shakir, M.; Ali, Q.; Rani, N.; Fatima, N.; Farooq, S.; Shafiq, S.; Kanwal, N.; Ali, F.; Nasir, I.A. Rhizobacteria and phytoremediation of heavy metals. Environ. Technol. Rev. 2016, 5, 112-119. [CrossRef]

18. Jegatheesan, V.; Ravishankar, H.; Shu, L.; Wang, J. Application of Green and Physico-Chemical Technologies in Treating Water Polluted by Heavy Metals. In Green Technologies for Sustainable Water Management; American Society of Civil Engineers: Reston, VA, USA, 2016; pp. 579-614.

19. Da Conceição Gomes, M.A.; Hauser-Davis, R.A.; de Souza, A.N.; Vitoria, A.P. Metal phytoremediation: General strategies, genetically modified plants and applications in metal nanoparticle contamination. Ecotoxicol. Environ. Saf. 2016, 134, 133-147. [CrossRef] [PubMed]

20. Kang, C.H.; Kwon, Y.J.; So, J.S. Bioremediation of heavy metals by using bacterial mixtures. Ecol. Eng. 2016, 89, 64-69. [CrossRef]

21. Mani, D.; Kumar, C. Biotechnological advances in bioremediation of heavy metals contaminated ecosystems: An overview with special reference to phytoremediation. Int. J. Environ. Sci. Technol. 2014, 11, 843-872. [CrossRef]

22. Chibuike, G.U.; Obiora, S.C. Heavy metal polluted soils: Effect on plants and bioremediation methods. Appl. Environ. Soil Sci. 2014. [CrossRef]

23. Kumar, A.; Bisht, B.S.; Joshi, V.D.; Dhewa, T. Review on bioremediation of polluted environment: A management tool. Int. J. Environ. Sci. 2011, 1, 1079-1093.

24. Ullah, A.; Heng, S.; Munis, M.F.H.; Fahad, S.; Yang, X. Phytoremediation of heavy metals assisted by plant growth promoting (PGP) bacteria: A review. Environ. Exp. Bot. 2015, 117, 28-40. [CrossRef]

25. Chang, P.; Gerhardt, K.E.; Huang, X.D.; Yu, X.M.; Glick, B.R.; Gerwing, P.D.; Greenberg, B.M. Plant growth-promoting bacteria facilitate the growth of barley and oats in salt-impacted soil: Implications for phytoremediation of saline soils. Int. J. Phytoremediat. 2014, 16, 1133-1147. [CrossRef]

26. Chaturvedi, R.; Varun, M.; Paul, M.S. Phytoremediation: Uptake and role of metal transporters in some members of Brassicaceae. In Phytoremediation; Springer International Publishing: Cham, Switzerland, 2016; pp. 453-468.

27. Mench, M.; Schwitzguebel, J.P.; Schroeder, P.; Bert, V.; Gawronski, S.; Gupta, S. Assessment of successful experiments and limitations of phyto technologies: Contaminant uptake, detoxification and sequestration, and consequences for food safety. Environ. Sci. Pollut. Res. 2009, 16, 876-900. [CrossRef] [PubMed] 
28. Munir, I.; Faisal, M. Plant growth-promoting bacteria: A good source for phytoremediation of metal-contaminated soil. In Phytoremediation; Springer: Cham, Switzerland, 2016; pp. 119-129.

29. Antonkiewicz, J.; Kołodziej, B.; Bielińska, E.J.; Witkowicz, R.; Tabor, S. Using Jerusalem Artichoke to Extract Heavy Metals from Municipal Sewage Sludge Amended Soil. Pol. J. Environ. Stud. 2018, 27, 513-527. [CrossRef]

30. Jaffre, T.; Pillon, Y.; Thomine, S.; Merlot, S. The metal hyperaccumulators from New Caledonia can broaden our understanding of nickel accumulation in plants. Front. Plant Sci. 2013, 4, 279. [CrossRef]

31. Glick, B. Plant Growth-promoting Bacteria: Mechanisms and Applications. Scientifica 2012. [CrossRef]

32. Assunçao, A.; Schat, H.; Aarts, M. Thlaspi caerulescens, an attractive model species to study heavy metal hyperaccumulation in plants. New Phytol. 2003, 159, 351-360. [CrossRef]

33. He, C.; Tan, G.; Liang, X.; Du, W.; Chen, Y.; Zhi, G. Effect of Zn-tolerant bacterial strains on growth and Zn accumulation in Orychophragmus violaceus. Appl. Soil. Ecol. 2010, 44, 1-5. [CrossRef]

34. Pierattini, E.C.; Francini, A.; Raffaelli, A.; Sebastiani, L. Surfactant and heavy metal interaction in poplar: A focus on SDS and Zn uptake. Tree Physiol. 2017, 38, 109-118. [CrossRef]

35. Ma, Y.; Rajkumar, M.; Zhang, C.; Freitas, H. Beneficial role of bacterial endophytes in heavy metal phytoremediation. J. Environ. Manag. 2016, 174, 14-25. [CrossRef] [PubMed]

36. Ribiero de Souza, S.C.; Andrade, S.A.L.; Souza, L.A.; Schiavinato, M.A. Lead tolerance and phytoremediation potential of Brazilian leguminous tree species at the seedling stage. J. Environ. Manag. 2012, 110, 299-307. [CrossRef] [PubMed]

37. Lievens, C.; Yperman, J.; Vangronsveld, J.; Carleer, R. Study of the potential valorisation of heavy metal contaminated biomass via phytoremediation by fast pyrolysis: Part I. Influence of temperature, biomass species and solid heat carrier on the behaviour of heavy metals. Fuel 2008, 87, 1894-1905. [CrossRef]

38. Prasad, M.N.V.; Freitas, H.M.O. Metal hyper accumulation in plants-Biodiversity prospecting for phytoremediation technology. Electron. J. Biotechnol. 2003, 6, 285-321. [CrossRef]

39. Koptsik, G.N. Problems and Prospects Concerning the Phytoremediation of Heavy Metal Polluted Soils: A Review. Eurasian Soil Sci. 2014, 47, 923-939. [CrossRef]

40. Mignardi, S.; Corami, A.; Ferrini, V. Evaluation of the effectiveness of phosphate treatment for the remediation of mine waste soils contaminated with $\mathrm{Cd}, \mathrm{Cu}, \mathrm{Pb}$, and $\mathrm{Zn}$. Chemosphere 2012, 86, 354-360. [CrossRef]

41. Arshad, M.; Silvestre, J.; Merlina, G.; Dumat, C.; Pinelli, E.; Kallerhoff, J. Thidiazuron induced shoot organogenesis from mature leaf explants of scented Pelargonium capitatum cultivars. Plant Cell Tissue Organ Cult. 2012, 108, 315-322. [CrossRef]

42. Evangelou, M.W.H.; Ebel, M.; Schaeffer, A. Chelate assisted phytoextraction of heavy metals from soil: Effect, mechanism, toxicity, and fate of chelating agents. Chemosphere 2007, 68, 989-1003. [CrossRef]

43. Souza, L.A.; Piotto, F.A.; Nogueiro, R.C.; Azevedo, R.A. Use of Non-Hyperaccumulator Plant Species for the Phytoextraction of Heavy Metals Using Chelating Agents. Sci. Agric. 2013, 70, 290-295. [CrossRef]

44. Iqbal, M.; Bakht, J.; Shafi, M.; Ullah, R. Effect of heavy metal and EDTA application on heavy metal uptake and gene expression in different Brassica species. Afr. J. Biotechnol. 2012, 11, 7649-7658.

45. Dipu, S.; Kumar, A.A.; Thanga, S.G. Effect of chelating agents in phytoremediation of heavy metals. Remediat. J. 2012, 22, 133-146. [CrossRef]

46. Shahid, M.; Dumat, C.; Pourrut, B.; Silvestre, J.; Laplanche, C.; Pinelli, E. Influence of EDTA and citric acid on lead-induced oxidative stress to Vicia faba roots. J. Soils Sediments 2014, 14, 835-843. [CrossRef]

47. Awokunmi, E.E.; Asaolu, S.S.; Ajayi, O.O.; Adebayo, O.A. The role of EDTA on heavy metals phytoextraction by Jatropha gossypifolia grown on soil collected from dumpsites in Ekiti state Nigeria. Br. J. Environ. Clim. Chang. 2012, 2, 153-162. [CrossRef]

48. Zhao, Z.; Xi, M.; Jiang, G.; Liu, X.; Bai, Z.; Huang, Y. Effects of IDSA, EDDS and EDTA on heavy metals accumulation in hydroponically grown maize (Zea mays, L.). J. Hazard. Mater. 2010, 181, 455-459. [CrossRef] [PubMed]

49. Sun, Y.; Zhou, Q.; Wang, L.; Liu, W. The influence of different growth stages and dosage of EDTA on Cd uptake and accumulation in Cd-hyperaccumulator (Solanum nigrum L.). Bull. Environ. Contam. Toxicol. 2009, 82, 348-353. [CrossRef] [PubMed]

50. Shahid, A.; Austruy, G.; Echevarria, M.; Arshad, M.; Sanaullah, M.; Aslam, M.; Nadeem, M.; Nasim, W.; Dumat, C. EDTA-Enhanced Phytoremediation of Heavy Metals: A Review. Soil Sediment Contam. Int. J. 2014, 23, 389-416. [CrossRef] 
51. Andra, S.S.; Datta, R.; Sarkar, D.; Saminathan, S.K.M.; Mullens, C.P.; Bach, S.B.H. Analysis of phytochelatin complexes in the lead tolerant vetiver grass Vetiveria zizanioides (L.) using liquid chromatography and mass spectrometry. Environ. Pollut. 2009, 157, 2173-2183. [CrossRef]

52. Gabos, M.B.; Abreu, C.A.D.; Coscione, A.R. EDTA assisted phytoremediation of a pb contaminated soil: Metal leaching and uptake by jack beans. Sci. Agric. 2009, 66, 506-514. [CrossRef]

53. Khan, S.; Hesham, A.E.L.; Qiao, M.; Rehman, S.; He, J.Z. Effects of Cd and Pb on soil microbial community structure and activities. Environ. Sci. Pollut. Res. 2010, 17, 288-296. [CrossRef]

54. Chen, Y.; Cutright, T. EDTA and HEDTA Effects on Cd, Cr, and Ni Uptake by Helianthus annuus. Chemosphere 2001, 45, 21-28. [CrossRef]

55. Jianv, L.; Qixing, Z.; Song, W. Evaluation of Chemical Enhancement on Phytoremediation Effect of Cd-Contaminated Soils with Calendula officinalis L. Int. J. Phytoremediat. 2010, 12, 503-515.

56. Malarkodi, M.; Krishnasamy, R.; Chitdeshwari, T. Phytoextraction of Nickel Contaminated Soil Using Castor Phytoextractor. J. Plant Nutr. 2008, 31, 219-229. [CrossRef]

57. Wei, J.; Lai, H.; Chen, Z. Chelator effects on bioconcentration and translocation of cadmium by hyperaccumulators, Tagetes patula and Impatiens walleriana. Ecotoxicol. Environ. Saf. 2012, 84, 173-178. [CrossRef] [PubMed]

58. Chigbo, C.; Batty, L. Effect of EDTA and citric acid on phytoremediation of Cr-B[a]P-co-contaminated soil. Environ. Sci. Pollut. Res. 2013, 20, 8955-8963. [CrossRef] [PubMed]

59. Markovskaa, Y.; Genevab, M.; Petrovb, P.; Boychinovab, M.; Lazarovac, I.; Todorovb, I.; Stancheva, I. EDTA Reduces Heavy Metal Impacts on Tribulus terrestris Photosynthesis and Antioxidants. Russ. J. Plant Physiol. 2013, 60, 623-632. [CrossRef]

60. Lai, H.-Y.; Chen, Z.S. Effects of EDTA on solubility of cadmium, zinc, and lead and their uptake by rainbow pink and vetiver grass. Chemosphere 2004, 55, 421-430. [CrossRef] [PubMed]

61. Vassil, A.D.; Kapulnik, Y.; Raskin, I.; Salt, D.E. The Role of EDTA in Lead Transport and Accumulation by Indian Mustard. Plant Physiol. 1998, 117, 447-453. [CrossRef] [PubMed]

62. Luo, C.; Shen, Z.; Li, X. Enhanced phytoextraction of $\mathrm{Cu}, \mathrm{Pb}, \mathrm{Zn}$, and Cd with EDTA and EDDS. Chemosphere 2005, 59, 1-11. [CrossRef]

63. Cui, Y.; Wang, Q.; Dong, Y.; Li, H.; Christie, P. Enhanced uptake of soil Pb and Zn by Indian mustard and winter wheat following combined soil application of elemental sulphur and EDTA. Plant Soil 2004, 261, 181-188. [CrossRef]

64. Wang, S.; Liu, J. The effectiveness and risk comparison of EDTA with EGTA in enhancing Cd phytoextraction by Mirabilis jalapa L. Environ. Monit. Assess. 2014, 186, 751-759. [CrossRef] [PubMed]

65. Liu, J.N.; Zhou, Q.X.; Wang, S.; Sun, T. Cadmium tolerance and accumulation of Althaea rosea Cav. And its potential as a hyperaccumulation under chemical enhancement. Environ. Monit. Assess. 2009, 149, 419-427. [CrossRef]

66. Sakouhi, L.; Rahoui, S.; Massoud, M.B.; Munemasa, S.; Ferjani, E.F.; Murata, Y.; Chaou, A. Calcium and EGTA Alleviate Cadmium Toxicity in Germinating Chickpea Seeds. J. Plant Growth Regul. 2016, 35, 1064-1073. [CrossRef]

67. Miller, G.; Begonia, G.; Begonia, M.; Ntoni, J.; Hundley, O. Assessment of the Efficacy of Chelate-Assisted Phytoextraction of Lead by Coffeeweed (Sesbania exaltata Raf.). Int. J. Environ. Res. Public Health 2008, 5, 428-435. [CrossRef] [PubMed]

68. Liu, J.-N.; Zhou, Q.; Sun, T.; Ma, L.Q.; Wang, S. Identification of and Chemical Enhancement of Two Ornamental Plants for Phytoremediation. Bull. Environ. Contam. Toxicol. 2008, 80, 260-265. [CrossRef] [PubMed]

69. Almeida, C.M.R.; Mucha, A.P.; Delgado, M.F.C.; Caçador, M.I.; Bordalo, A.A.; Vasconcelos, M.T.S.D. Can PAHs influence $\mathrm{Cu}$ accumulation by salt marsh plants. Mar. Environ. Res. 2008, 66, 311-318. [CrossRef]

70. Saifullah, M.E.; Qadir, M.; de Caritat, P.; Tack, F.M.G.; Du Laing, G.; Zia, M.H. EDTA-assisted Pbphytoextraction. Chemosphere 2009, 74, 1279-1291. [CrossRef]

71. Degryse, F.; Smolders, E.; Merckx, R. Labile Cd complexes increase Cd availability to plants. Environ. Sci. Technol. 2006, 40, 830-836. [CrossRef]

72. Seregin, I.V.; Ivanov, V.B. Physiological aspects of cadmium and lead toxic effects on higher plants. Russ. J. Plant Physiol. 2001, 48, 523-544. [CrossRef] 
73. Pourrut, B.; Shahid, M.; Dumat, C.; Winterton, P.; Pinelli, E. Lead uptake, toxicity and detoxification in plants. Rev. Environ. Contam. Toxicol. 2011, 213, 113-131. [PubMed]

74. Wu, L.; Li, Z.; Akahane, I.; Liu, L.; Han, C.; Makino, T.; Luo, Y.; Christie, P. Effects of organic amendments on $\mathrm{Cd}, \mathrm{Zn}$ and $\mathrm{Cu}$ bioavailability in soil with repeated phytoremediation by Sedum plumbizincicola. Int. J. Phytoremediat. 2012, 14, 1024-1038. [CrossRef]

75. Sarret, G.; Vangronsveld, J.; Manceau, A.; Musso, M.; D’Haen, J.; Menthonnex, J.J.; Hazemann, J.L. Accumulation forms of $\mathrm{Zn}$ and $\mathrm{Pb}$ in Phaseolus vulgaris in the presence and absence of EDTA. Environ. Sci. Technol. 2001, 35, 2854-2859. [CrossRef]

76. Schaider, L.; Parker, D.; Sedlak, D. Uptake of EDTA-complexed Pb, Cd and Fe by solution-and sand-cultured Brassica juncea. Plant Soil 2006, 286, 377-391. [CrossRef]

77. Pereira, B.F.F.; de Abreu, C.A.; Herpin, U.; de Abreu, M.F.; Berton, R.S. Phytoremediation of lead by jack beans on a RhodicHapludox amended with EDTA. Sci. Agric. 2010, 67, 308-318. [CrossRef]

78. Messina, C.M.; Faggio, C.; Laudicella, V.A.; Sanfilippo, M.; Trischitta, F.; Santulli, A. Effect of sodium dodecyl sulfate (SDS) on stress response in the Mediterranean mussel (Mytilus galloprovincialis): Regulatory volume decrease (Rvd) and modulation of biochemical markers related to oxidative stress. Aquat. Toxicol. 2014, 157, 94-100. [CrossRef] [PubMed]

79. Ramamurthy, A.; Schalchian, H. Surfactant assisted removal of $\mathrm{Cu}(\mathrm{II}), \mathrm{Cd}(\mathrm{II})$ and $\mathrm{Pb}$ (II) from contaminated soils. Environ. Prot. Eng. 2013, 39, 87-99.

80. Wang, J.; Wang, J.; Xu, C.; Liu, R.; Chen, Y. Molecular mechanism of catalase activity change under sodium dodecyl sulfate-induced oxidative stress in the mouse primary hepatocytes. J. Hazard. Mater. 2016, 307, 173-183. [CrossRef] [PubMed]

81. Chaturvedi, V.; Kumar, A. Isolation of a strain of Pseudomonas putida capable of metabolizing anionic detergent sodium dodecyl sulfate (SDS). Iran. J. Microbiol. 2011, 3, 47-53.

82. Paulo, A.M.S.; Plugge, C.M.; García-Encina, P.A.; Stams, A.J.M. Anaerobic degradation of sodium dodecyl sulfate (SDS) by denitrifying bacteria. Int. Biodeterior. Biodegrad. 2013, 84, 14-20. [CrossRef]

83. Nguyen, H.M.; Phan, C.M.; Sen, T. Degradation of sodium dodecyl sulfate by photoelectrochemical and electrochemical processes. Chem. Eng. J. 2016, 287, 633-639. [CrossRef]

84. Lambrechts, T.; Gustot, Q.; Couder, E.; Houben, D.; Iserentant, A.; Lutts, S. Comparison of EDTA-enhanced phytoextraction and phytostabilisation strategies with Loliumperenne on a heavy metal contaminated soil. Chemosphere 2011, 85, 1290-1298. [CrossRef] [PubMed]

85. Muhlbachov, A.G. Soil microbial activities and heavy metal mobility in long-term contaminated soils after addition of EDTA and EDDS. Ecol. Eng. 2011, 37, 1064-1071. [CrossRef]

86. Neugschwandtner, R.W.; Tlustos, P.; Komarek, M.; Szakov, J.; Jakoubkova, L. Chemically enhanced phytoextraction of risk elements from a contaminated agricultural soil using Zea mays and Triticumaestivum: Performance and metal mobilization over a three year period. Int. J. Phytoremediat. 2012, 14, 754-771. [CrossRef]

87. Goel, S.; Gautam, A. Effect of chelating agents on mobilization of metal from waste catalyst. Hydrometallurgy 2010, 101, 120-125. [CrossRef]

88. Meers, E.; Ruttens, A.; Hopgood, M.; Lesage, E.; Tack, F.M.G. Potential of Brassicrapa, Cannabis sativa, Helianthus annuus and Zea mays for phytoextraction of heavy metals from calcareous dredged sediment derived soils. Chemosphere 2005, 61, 561-572. [CrossRef] [PubMed]

89. Grcman, H.; Velikonja-Bolta, S.; Vodnik, D.; Kos, B.; Lestan, D. EDTA enhanced heavy metal phytoextraction: Metal accumulation, leaching and toxicity. Plant Soil 2001, 235, 105-114. [CrossRef]

90. Luo, C.; Shen, Z.; Li, X.; Baker, A.J.M. The role of root damage in the chelate-enhanced accumulation of lead by Indian mustard plants. Int. J. Phytoremdiat. 2006, 8, 323-337. [CrossRef]

91. Krujatz, F. Assessing the toxic effects of nickel, cadmium and EDTA on growth of the plant growth-promoting rhizobacterium Pseudomonas brassicacearum. Water Air Soil Pollut. 2012, 223, 1281-1293. [CrossRef]

92. Ruley, A.T.; Sharma, N.C.; Sahi, S.V. Antioxidant defense in a lead accumulating plant, Sesbaniadrummondii. Plant Physiol. Biochem. 2004, 42, 899-906. [CrossRef]

93. Hadi, F.; Bano, A.; Fuller, M.P. The improved phytoextraction of lead ( $\mathrm{Pb})$ and the growth of maize (Zea mays L.): The role of plant growth regulators (GA3 and IAA) and EDTA alone and in combinations. Chemosphere 2010, 80, 457-462. [CrossRef] 
94. Ruley, A.T.; Sharma, N.C.; Sahi, S.V.; Singh, S.R.; Sajwan, K.S. Effects of lead and chelators on growth, photosynthetic activity and $\mathrm{Pb}$ uptake in Sesbaniadrummondii grown in soil. Environ. Pollut. 2001, 144, 11-18. [CrossRef] [PubMed]

95. Xu, W.; Li, W.; He, J.; Balwant, S.; Xiong, Z. Effects of insoluble Zn, Cd, and EDTA on the growth, activities of antioxidant enzymes and uptake of Zn and Cd in Vetiveriazizanioides. J. Environ. Sci. 2010, 21, 186-192. [CrossRef]

96. Muhammad, D.; Chen, F.; Zhao, J.; Zhang, G.; Wu, F. Comparison of EDTA- and citric acid-enhanced phytoextraction of heavy metals in artificially metal contaminated soil by Typhaangustifolia. Int. J. Phytoremediat. 2009, 11, 558-574. [CrossRef]

97. Sanaullah, M.; Blagodatskaya, E.; Chabbi, A.; Rumpel, C.; Kuzyakov, Y. Drought effects on microbial biomass and enzyme activities in the rhizosphere of grasses depend on plant community composition. Appl. Soil Ecol. 2011, 48, 38-44. [CrossRef]

98. Saifullah, G.A.; Zia, M.H.; Murtaza, G.; Waraich, E.A.; Bibi, S.; Srivastava, P. Comparison of organic and inorganic amendments for enhancing soil lead phytoextraction by wheat (Triticum aestivum L.). Int. J. Phytoremediat. 2010, 12, 633-649. [CrossRef] [PubMed]

99. Jean-Soro, L.; Bordas, F.; Bollinger, J.C. Column leaching of chromium and nickel from a contaminated soil using EDTA and citric acid. Environ. Pollut. 2012, 164, 175-181. [CrossRef] [PubMed]

(C) 2019 by the authors. Licensee MDPI, Basel, Switzerland. This article is an open access article distributed under the terms and conditions of the Creative Commons Attribution (CC BY) license (http://creativecommons.org/licenses/by/4.0/). 